Effectiveness of the existing $\&$ introduced management mechanisms for the management of Negombo estuarine

$$
\text { system }
$$

By

Koku Hennadige Ruwan Sriyantha

Thesis submitted to the University of Sri Jayewardenepura for award of the of the Degree of Master of Science in Fisheries and Aquatic Resource Management. 


\section{Memorandum}

"The work described in this thesis was carried out by me at the Department of Zoology, University of Sri Jayewardenepura, Nugegoda, Sri Lanka under the supervision of Dr. Ajantha De Alwis and a report on this has not been submitted in whole or in part to any university or any other institution for another Degree".

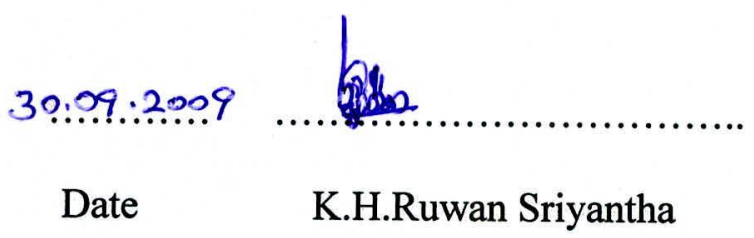




\section{Certification}

We certify that the work of K.H.R.Sriyantha on Effectiveness of the existing \& introduced management mechanisms for the management of Negombo estuarine system for the degree of Master of Science in Fisheries and Aquatic Resource Management in the Faculty of Science at University of Sri Jayewardenepura, Nugegoda, Sri Lanka.

We feel that the candidate's work is complete and suitable for submitting to the University for the purpose of evaluation"

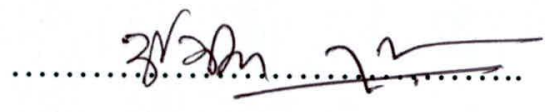

Supervisor

Dr. (Mrs.) Ajantha de Alwis, Senior Lecturer, Department of Zoology, University of Sri Jayewardenepura.

Date ..3.....9...200.9......

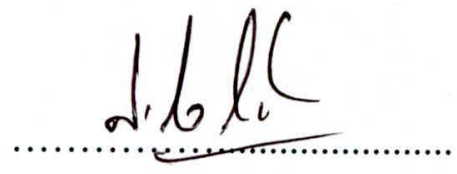

Head of the Department

Dr. B.G.N. K. De Silva, Department of Zoology, University of Sri Jayewardenepura

Date....30 09.....8049...... 


\section{LIST OF CONTENT}

CONTENT

PAGE

LIST OF CONTENTS

LIST OF TABLES

III

LIST OF FIGURES

IV

LIST OF ANNEXES

IV

ABBREVIATIONS

V

ACKNOWLEDGEMENTS

VI

ABSTRACT

VII

CHAPTER 1

1

1.0 Introduction

1

CHAPTER 2

7

2.0 Materials and methods

7

$\begin{array}{lll}2.1 & \text { Primary information } & 7\end{array}$

$\begin{array}{ll}\text { 2.1.1 Field observations } & 7\end{array}$

2.1.2 Questionnaire-based data collection $\quad 8$

2.2 Secondary data 9 


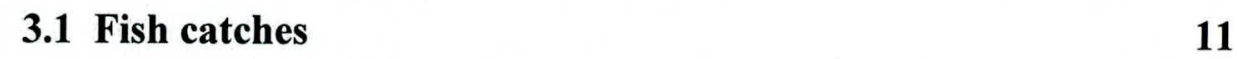

3.1.1 Fishing crafts and gear $\quad 11$

3.1.2 Monthly fish and shrimp production $\quad 12$

3.1.3 Species composition fish in the catches of the selected sites 14

$\begin{array}{ll}\text { 3.1.4 Prices of shrimp and fish species } & 14\end{array}$

3.1.5 Income Level of fishermen $\quad 17$

3.1.6. Water quality parameters of Negombo Estuary 18

CHAPTER 4 - DISCUSSION 28

CHAPTER 5- CONCLUSIONS

CHAPTER 6- REFERENCES 36

LIST OF ANNEXES 


\section{LIST OF TABLES}

Table 2.1 Details of sampling sites

8

Table 3.1 Monthly projected production data for 78 traditional landing sites in

Negombo estuarine system

Table 3.2 Fish Composition in the catches in Negombo estuary 


\section{LIST OF FIGURES}

Fig.1.1 Arial view of Negombo Estuary 1

Fig 2.1 Sampling sites of the present study in the Negombo estuary 10

Fig. 3.1 Average monthly catch for 10 traditional landing sites 12

Fig. 3.2 Average pH values of Negombo estuary from 1977-2008 19

Fig. 3.3 Average Temperature values of Negombo estuary from 1981-2008 20

Fig. 3.4 Average Dissolved Oxygen values of Negombo estuary from 1977-2008 21

Fig. 3.5 Average salinity values of Negombo estuary from 1970-2008 22

Fig. 3.6 Average Phosphate values of Negombo estuary from 1991-2008 23

Fig. 3.7 Average Nitrate values of Negombo estuary from 1988-2008 24

Fig. 3.8 Average Nitrite values of Negombo estuary from 1991-2008 25

Fig. 3.9 Average Ammonia values of Negombo estuary from 1991-2003 26

Fig. 3.10 Average Conductivity values of Negombo estuary from 1991-2008 27

\section{LIST OF ANNEXES}

Annex 1- Questionnaire $\quad 39$

Annex 2 - Water Quality Standards of Sri Lanka $\quad 40$ 


\section{ABBREVIATIONS}

BOI - Board of Investment

CBO - Community Base Organization

CCC - Community Coordinating Committee

CCD - Coast Conservation Department

CEA - Central Environment Authority

CRMP - Coastal Resources Management Project

DS - Divisional Secretariat

DWLC - Department of Wildlife Conservation

FI - Fisheries Inspector

FPIU - Field Project Implementation Unit

GCEC - Greater Colombo Economic Commission

GN - - Grama Niladhari

MC - Municipal Council

NARA - National Aquatic Resources Research and Development Agency

NGO - Non Government Organization

NLFMA - Negombo Lagoon Fishery Management Area

SAM - Special Area Management

UDA - Urban Development Authority.

UoM - University of Moratuwa 


\section{ACKNOWLEDGEMENTS}

I wish to express my deepest gratitude with sincere thanks to my supervisor Dr. (Mrs.)

Ajantha de Alvis, Senior Lecturer, Department of Zoology, University of Sri Jayawardenepura for her dedicated guidance and encouragement given me at all stages of this study.

I am grateful to Eng H.N.R.Perera, Director/Coast Conservation for providing necessary facilities to carry out this study.

I am also grateful to Mr. Anil Premaratne, Additional Director, Mr. Gamini Hewage Deputy Director of Coast Conservation Department and Mr. Indra Ranasinghe , Actg. Director General (Development ), Ministry of Fisheries \& Aquatic Resources for their valuable suggestions, and advice during the study

I also wish to thank all members of the academic and non-academic and technical staff of the Department of Zoology, University of University of Sri Jayawardenepura for helping me in numerous ways.

I wish to convey a special thanks to Dr. Wasantha Pahalawattaarachchi, Mr. D.D.G.L. Dahanayaka, Mr. Ajith, Mr. Suresh Kumar and the staff of the NARA for helping me in numerous ways. Also I wish to special thank Mr. Joseph and Mr. Ananda of Deputy Manager of CRMP project, Negombo for the invaluable support given to me during the study period .

Finally, I thanks my family members for tolerating me as always when I needed them. 


\title{
Effectiveness of the existing $\&$ introduced management mechanisms for the management of Negombo estuarine system
}

\author{
K. H. R. Sriyantha
}

\begin{abstract}
The economic value of Negombo estuarine system has come under threat during the last three decades as the demand for various resources of the system increased. During the recent past there has been visible degradation of this system

In order to improve the environment and socio economic situation of this estuarine ecosystem, 'Special Area Management Plan for Negombo Lagoon' is being implemented by the Coast Conservation Department It is of paramount importance to evaluate the success of these implementations to make sure that the interventions are feasible so that they can be adopted for other lagoon and estuarine systems in the future. In this respect, this research was carried out to evaluate the effectiveness of one of the most important management strategies and initiatives taken, namely, the implementation of dredging of the estuary banks. Primary and secondary information on commercial fish/shrimp catches , water quality parameters and socio economics conditions of the fishing community were collected over a period of 12 months from May 2008 to April 2009.
\end{abstract}

The results of this study reveals that the completed dredging programme has brought in positive results. It has helped to increase the fish/shrimp catches from the estuarine system 
as there is a $14.21 \%$ of increase in $2008-2009 \mathrm{fish} / \mathrm{shrimp}$ catches compared to 2001 . As a result of this increase, the socio-economic conditions of the communities that depend on this water body also has improved. However, the analysis of water quality data shows that the dredging has not had any positive effects on the water quality of the estuary. It reveals a eutrophic condition which has to be rectified immediately in order to manage the resources associated with the estuary. For this the implementation of main dredging programme which includes the dredging of sea mouth is of utmost importance. It is also equally important to control the point sources of discharges to the estuary. 


\section{CHAPTER 1}

\subsection{Introduction}

Negombo estuarine system is located $35 \mathrm{~km}$ from North of Colombo on the western coast in Sri Lanka ( at $7^{\circ} 7^{\prime} \mathrm{N}$ and $79^{\circ} 50^{\prime} \mathrm{E}$ ). It runs alongside the Indian Ocean together with the Muthurajawela marsh. This system is situated in Negombo and Ja-Ela Divisional Secretariat in Gampaha District of the Western Province of the country. Fig. 1.1 shows an aerial view of the Negombo estuary.

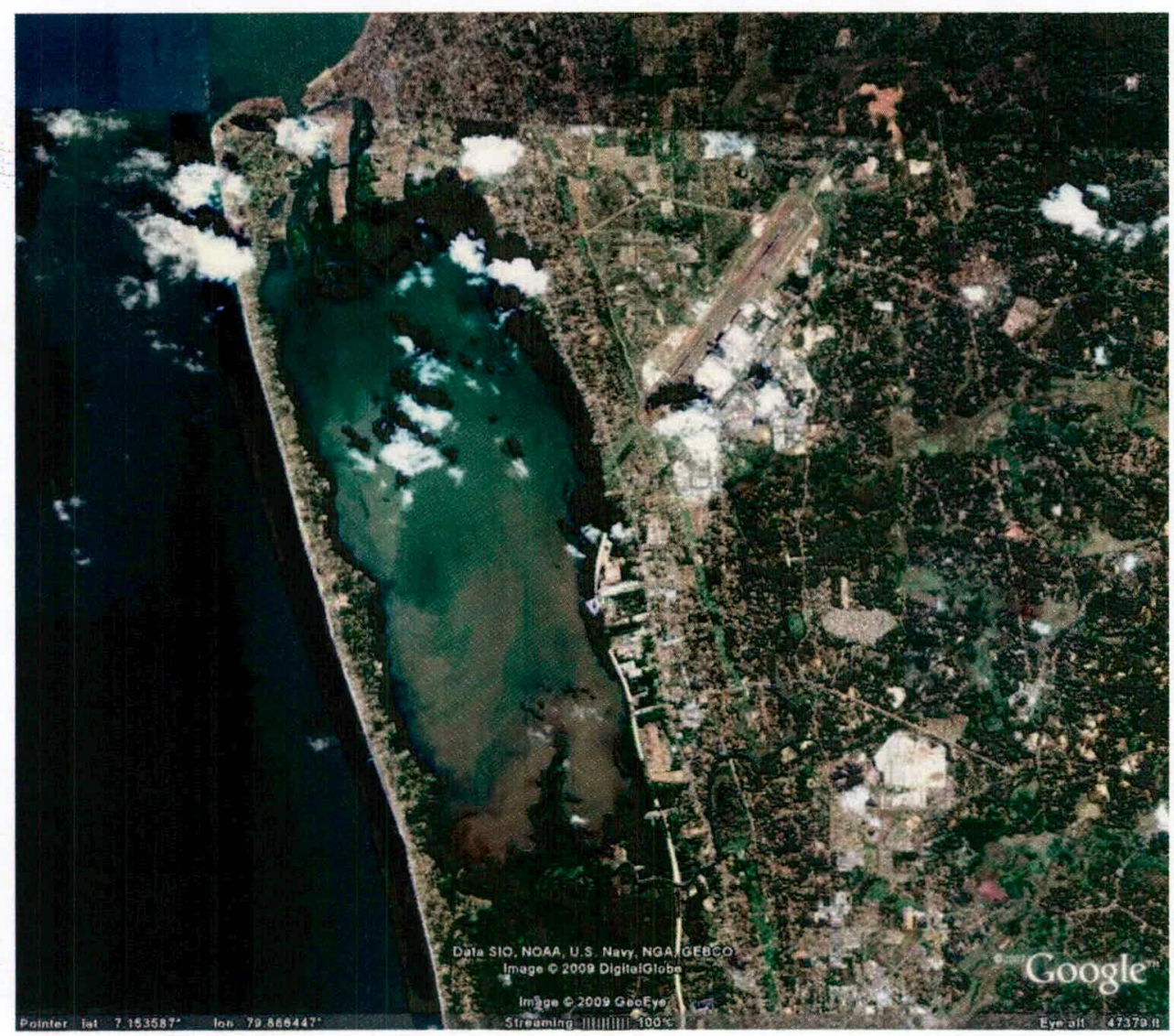

Figure 1.1 -Arial view of Negombo Estuary (Source : Google earth) 
The Muthurajwela marsh and Negombo estuary is a wetland ecosystem with many special characteristics. This wetland ecosystem is 6232 ha in extent. Negombo estuary is a relatively small bar built basin estuary. It is 3164 ha in extent. The Muthurajwela marsh (3068 ha) extends southward from the estuary. Negombo estuary has water area of above 3200 ha (Maddumabandara,1988). Its length is approximately $12.5 \mathrm{~km}$. and width varies between $0.6 \mathrm{~km}$ to $3.75 \mathrm{~km}$. The greatest recorded water depth is $2.6 \mathrm{~m}$ but $10 \%$ of the estuary has a water depth of less than $0.5 \mathrm{~m}$. The mean depth of the estuary is about 0.65 $\mathrm{m}$. It is a relatively shallow estuary. The entire wetland is separated from the sea by a sand barrier (CCD,2005).

The water exchange in the estuary is influenced by tides and freshwater supply. Estuary is permanently connected with the sea at its northern end by a narrow opening and connected to the Muthurajawela marsh at its southern end. Inlet of the estuary consists of several narrow channels. The main channel has a length of $2 \mathrm{~km}$, a mean depth of $2 \mathrm{~m}$, and an average width of $150 \mathrm{~m}$. Negombo estuary may be divided into a channel segment and a basin segment. The tidal range is the estuary varies in the order of $0.07 \mathrm{~m}$ at neaps to $0.2 \mathrm{~m}$ at springs (CEA, 1999). The high tide brings seawater into the estuary twice a day.

Freshwater enters from the southern end of the estuary through the rivers Dadugam Oya and Ja-ela. There is also a connection through the Hamilton Canal to the River Kelani Ganga. The supply of freshwater varies from practically zero during dry seasons to more than $100 \mathrm{~m}^{3} \mathrm{~s}^{-1}$ during rain periods. Accordingly, the salinity varies from very low values to 
above 30 ppt (personal communication G. Ranatunga, National Aquatic Resources Agency). Freshwater from a watershed of $720 \mathrm{~km}^{2}$ drains at the junction of the estuary and the marsh via above sources (CCD,2005). Continuous mixing of these freshwater and seawaters has led to a brackish ecosystem, with high productivity and high biological diversity.

The estuary consists of a variety of coastal habitats such as mangroves, estuarine coastal wetland vegetation and sea grass beds. Mangroves and sea grass bed of the estuary are of particular importance as they act as a silt trap and provide spawning, nursing, feeding grounds and shelter for a variety of economically important fish and shrimp species.

The estuary also supports a fishery which is estimated at $698 \mathrm{mt} /$ year (Jayawardena, 2002). More than 3500 fishermen depend on the fish catches in the estuary. The Negombo anchorage in the estuary provides operating facilities for about 3086 sea going fishing crafts (CCD, 2005) which is about $15 \%$ of Sri Lanka's fishing fleet. This estuarine system also has other functions such as a sink for urban run off, sink for industrial effluents, recreation, providing land for housing and industry (through encroachments), providing wood, vegetables and medicines, functioning as a centre for education and ecosystem research, flood protection, among others. 
The Negombo estuary together with Muthurajawela Marsh has been declared as a wetland under the Ramsar convention and the area is a site of high biodiversity in Sri Lanka (CEA, 1991).

Negombo estuary also has a great history of its own. It was a foremost seaport in Sri Lanka during the period of the Kotte Kingdom under the Portuguese. However, its importance as a port declined under the Dutch. This ecosystem has served multiple uses including fishery, agriculture, trade and shipping and habitation from the past. For instance, since the $15^{\text {th }}$ century, it was an important centre for fisheries.

The very economic value of this important system has come under threat during the last three decades as the demand for various resources of the system increased. During the recent past there has been visible degradation of this system due to urbanization, industrialization, high population densities, over exploitation of natural resources, insufficient exchange of sea water due to sedimentation in the canal and southern reaches of estuary, human activities, unplanned development and weakness of the resource management approaches. Also, numerous environment and socio-economic problems have arisen during the last three decades. These problems and issues can be grouped in to three, namely, Environmental Issues (i.e. Degradation of certain habitats, Pollution due to discharge of industrial waste, Solid waste dumping, Sedimentation of the estuary, Poor water exchange with the sea, Declining biodiversity), Social Issues (i.e. Encroachment on the estuary, Poor sanitation among low income groups, Unemployment, Alcoholism, 